\title{
PENGARUH MOTIVASI DAN DISIPLIN BELAJAR TERHADAP KREATIVITAS BELAJAR MAHASISWA
}

\author{
Suharni \\ Program Studi Bimbingan dan Konseling \\ Fakultas Keguruan dan Ilmu Pendidikan \\ Universitas PGRI Yogyakarta \\ E-mail: suharni911@gmail.com
}

\begin{abstract}
Abstrak
Tujuan penelitian ini untuk mengetahui (1) Pengaruh disiplin belajar terhadap Kreativitas Balajar Mahasiswa Bimbingan dan Konseling Universitas PGRI Yogyakarta; (2) Pengaruh motivasi belajar terhadap Kreativitas Balajar Mahasiswa Bimbingan dan Konseling Universitas PGRI Yogyakarta; dan (3) Pengaruh kedisiplin belajar serta motivasi belajar terhadap Kreativitas Balajar Mahasiswa Bimbingan dan Konseling Universitas PGRI Yogyakarta. Jenis penelitian ini ex-post facto dengan populasi penelitian ini 149 Mahasiswa Bimbingan dan Konseling Universitas PGRI Yogyakarta. Analisis data yang digunakan adalah teknik analisis regresi sederhana dan analisis regresi ganda. Hasil dari penelitian: (1) Disiplin belajar memiliki pengaruh positif dan signifikan terhadap Kreativitas Belajar mahasiswa; (2) Motivasi belajar memiliki pengaruh positif dan signifikan terhadap Kreativitas Balajar Mahasiswa; dan (3) Disiplin belajar serta motivasi belajar secara bersama-sama memiliki pengaruh yang positif dan signifikan terhadap Kreativitas Balajar Mahasiswa dengan nilai Ry 1,2=0,394 > 0,206 r-tabel serta nilai Fhitung $(8,55)>$ Ftabel .
\end{abstract}

Kata kunci: disiplin belajar, motivasi belajar, kreativitas belajar

\begin{abstract}
The purpose of this study to determine (1) The influence of learning discipline on Student Creativity of Student Guidance and Counseling University PGRI Yogyakarta; (2) The influence of learning motivation toward Student Creativity of Guidance and Counseling of Universitas PGRI Yogyakarta; and (3) The influence of learning discipline and learning motivation toward Student Creativity of Guidance and Counseling of Universitas PGRI Yogyakarta. This type of research is ex-post facto with this research population 149 Students Guidance and Counseling University PGRI Yogyakarta. Data analysis used is simple regression analysis technique and multiple regression analysis. The results of the study: (1) Discipline learning has a positive and significant influence on Student Learning Creativity; (2) learning motivation has positive and significant influence on Student Creativity; and (3) learning discipline and learning motivation together have positive and significant influence on Student Creativity with Ry value 1,2 = 0,394>0,206 r-table and Fcount (8,55)> Ftabel.
\end{abstract}

Key words: discipline of learning, learning motivation, creativity of learning

Info Artikel

Diterima Oktober 2017, disetujui November 2017, diterbitkan Desember 2017

Dipublikasikan Oleh: Program Studi Bimbingan dan Konseling 


\section{PENDAHULUAN}

Pendidikan merupakan sarana mutlak yang dipergunakan untuk mewujudkan masyarakat madani yang mampu menguasai, mengembangkan, mengendalikan dan memanfaatkan ilmu pengetahuan dan teknologi. Output pendidikan belum mampu berjalan seimbang dengan tuntutan zaman, hal ini disebabkan minimnya penguasaan terhadap disiplin ilmu yang diperoleh melalui proses pendidikan. Keadaan ini menjadi tantangan bagi para pendidik untuk mempersiapkan peserta didiknya dalam memasuki masa depan

Belajar merupakan kegiatan yang berproses dan merupakan unsur yang sangat fundamental dalam menyelenggarakan setiap jenis dan jenjang pendidikan. Menurut Slameto (2003: 2) belajar adalah suatu proses usaha dilakukan seseorang untuk memperoleh suatu perubahan tingkah laku yang beru secara keseluruhan, sebagai hasil pengalamannya sendiri dalam interaksi dengan lingkungannya. Hal ini sejalan dengan yang diungkapkan oleh Wortman, Liffus, dan Marshal (Supartin, 2005: 2), bahwa belajar merupakan proses mental individu yang kompleks dan biasanya menghasilkan perubahan tingkah laku dan pola pikir pelajar, sehingga adanya perubahan dapat dikatakan sebagai kegiatan belajar. Lebih lanjut Sukmadinata (2003: 177) menyatakan bahwa: Kegiatan belajar yang berlangsung di sekolah formal, disengaja, direncanakan dengan bimbingan guru serta pendidik lainnya. Apa yang hendaknya dicapai dan dikuasai Mahasiswa (tujuan belajar), bahan apa yang harus dipelajari (bahan ajar), bagaimana cara Mahasiswa mempelajarinya (metode pembelajaran), serta bagaimana cara mengetahui kemajuan belajar Mahasiswa (evaluasi), telah direncanakan dengan seksama dalam kurikulum sekolah. Kegiatan belajar yang dilaksanakan di sekolah benarbenar disengaja dan direncanakan.Keberhasilan belajar seseorang diukur dari Kreativitas Balajarnya.

Kreativitas Balajar didefinisikan, seberapa jauh hasil yang sudah didapat Mahasiswa 2 dalam penguasaan tugas-tugas atau materi pelajaran yang diterima dalam waktu tertentu. Menurut Sukmadinata (2005: 56), prestasi atau hasil belajar (achievement) merupakan realisasi dari kecakapan-kecakapan potensial atau kapasitas yang dimiliki seseorang. Penguasaan hasil belajar dapat dilihat dari perilakunya, baik perilaku dalam bentuk penguasaan pengetahuan, keterampilan berpikir maupun keterampilan motorik. Di sekolah, hasil belajar atau Kreativitas Balajar ini dapat dilihat dari penguasaan Mahasiswa akan mata pelajaran yang telah ditempuhnya. Kreativitas Balajar atau hasil belajar merupakan bagian terpenting dalam pembelajaran.Sudjana (2009: 3) mendefinisikan hasil belajar Mahasiswa pada hakikatnya adalah 
perubahan tingkah laku sebagai hasil belajar dalam pengertian yang lebih luas mencakup bidang kognitif, afektif, dan psikomotorik.Dimyati dan Mudjiono (2006: 3) menyebutkan hasil belajar merupakan hasil dari suatu interaksi tindak belajar dan tindak mengajar.

Aktivitas belajar bagi setiap individu, tidak selamanya dapat berlangsung secara wajar. Kadangkadang lancar, kadang-kadang tidak, kadang-kadang dapat cepat menangkap apa yang dipelajari dan terkadang juga teramat sulit. Dalam hal semangat terkadang semangat tinggi, tetapi juga terkadang sulit untuk mengadakan konsentrasi.

Demikian kenyataan yang sering kita jumpai pada setiap anak didik dalam kehidupan sehari-hari dalam kaitannya dengan aktivitas belajar. Setiap individu memang tidak ada yang sama, perbedaan individual ini yang menyebabkan perbedaan tingkah laku belajar di kalangan anak didik. Dalam keadaan dimana anak didik atau Mahasiswa tidak dapat belajar sebagai mana mestinya, itulah yang dinamakan kesulitan belajar.

Tingginya minat Mahasiswa-siswi sekolah formal mengikuti bimbingan belajar merupakan simbol ketidakpercayaan Mahasiswa dan orangtua Mahasiswa terhadap proses pembelajaran di sekolah formal. Karenanya, sekolah harus memperbaiki pelayanannya kepada Mahasiswa untuk mengembalikan kepercayaan.Pengamat pendidikan yang juga seorang pendidik, St Kartono, mengungkapkan dengan mengikuti bimbingan belajar berarti Mahasiswa maupun orangtua Mahasiswa yang mengirimkan anak mereka untuk mengikuti bimbingan belajar cenderung tidak percaya bahwa pembelajaran di sekolah mampu membawa anak mereka bisa lebih berprestasi. Peneliti tertarik untuk melakukan penelitian dengan judul "PENGARUH MOTIVASI DAN DISIPLIN BELAJAR TERHADAP KREATIVITAS BELAJAR MAHASISWA SEMESTER III PROGRAM STUDI BIMBINGAN DAN KONSELING TAHUN AKADEMIK 2016/2017.

Selain motivasi belajar, kreativitas merupakan faktor intrenal lain yang dapat menentukan Kreativitas Balajar Mahasiswa. Munandar (2009: 38) menyatakan kreativitas merupakan kemampuan berpikir divergen atau pemikiran menjajaki bermacam-macam alternatif jawaban terhadap suatu persoalan, yang sama benarnya. Sedangkan menurut Rogers (dalam Zulkarnain, 2002: 45), kreativitas merupakan kecenderungan-kecenderungan manusia untuk mengaktualisasikan dirinya sesuai dengan kemampuan yang dimilikinya. Kreativitas yang timbul antara Mahasiswa satu dengan yang lain berbedabeda. Ada Mahasiswa yang berkreativitas tinggi dan ada Mahasiswa yang berkreativitas yang rendah, sehingga aktivitas yang dilakukan berbeda pula 
tergantung tinggi rendahnya kreativitas yang ada pada diri Mahasiswa. Semakin Mahasiswa memiliki kreativitas yang tinggi maka Mahasiswa tersebut akan semakin giat dalam belajarnya untuk mencapai prestasi yang maksimal. 4 Kreativitas merupakan suatu tuntutan pendidikan dan kehidupan yang sangat penting pada saat ini. Kreativitas akan menghasilkan berbagai inovasi dan perkembangan baru dalam kehidupan. Individu dan organisasi yang kreatif akan selalu dibutuhkan oleh lingkungannya karena mereka akan mampu memenuhi kebutuhan lingkungan yang terus berubah dan mampu bertahan dalam kompetisi global yang dinamis dan ketat. Pada dasarnya setiap anak memiliki potensi kreatif pada dirinya.

\section{KAJIAN TEORI}

\section{Disiplin Belajar}

Kata disiplin berasal dari bahasa latin disibel yang berarti pengikut. Seiring dengan perkembangan zaman, kata tersebut mengalami perubahan menjadi disipline yang artinya kepatuhan atau yang menyangkut tata tertib. Sejalan dengan hal tersebut Rahman (2011: 64) mengungkapkan bahwa "disiplin berasal dari bahasa Inggris discipline yang mengandung beberapa arti. Diantaranya adalah pengendalian diri, membentuk karakter yang bermoral, memperbaiki dengan sanksi, serta kumpulan beberapa tata tertib untuk mengatur tingkah laku. Dalam proses belajar sangatlah diperlukan sikap disiplin, Slameto (2013: 2) mengungkapkan bahwa "belajar merupakan suatu proses perubahan yang diperoleh dari usaha yang dilakukan seseorang untuk memperoleh suatu perubahan tingkah laku yang baru secara keseluruhan, sebagai hasil pengalamannya sendiri dalam interaksi dengan lingkungannya". Kemudian menurut Moenir (2010: 94-96) "Disiplin adalah suatu bentuk ketaatan terhadap aturan, baik tertulis maupun tidak tertulis yang telah ditetapkan.

Ada dua jenis disiplin yang sangat dominan sesuai dengan apa yang dikehendaki individu. Pertama disiplin dalam hal waktu dan disiplin kerja atau perbuatan". Dengan demikian kedua jenis disiplin yang dikemukakan oleh Moenir tersebut merupakan kesatuan yang tidak dapat dipisahkan serta saling mempengaruhi, contohnya apabila seorang anak hadir tepat waktu kesekolah tidak datang terlambat pada waktu jam pelajaran dimulai, tetapi ia tidak segera melakukan hal yang sesuai ketentuannya sebagai pelajar didalam kelas seperti tidak langsung membuka buku mata pelajarannya melainkan mengobrol dengan temannya tentunya ini akan merugikan anak itu sendiri, dengan demikian disiplin mendorong mahasiswa belajar secara konkrit baik di sekolah maupun dirumah. Disiplin sangat penting dalam kegiatan belajar mengajar di sekolah. 


\section{Indikator Disiplin}

Disiplin dalam penentuan seseorang dapat dikatakan memiliki sikap disiplin tentu ada beberapa sikap yang mencerminkan disiplin nya seperti indikator disiplin yang dikemukaan Tu'u (2004: 91) dalam penelitian mengenai disiplin sekolah mengemukakan bahwa "indikator yang menunjukan perubahan hasil belajar mahasiswa sebagai kontribusi mengikuti dan menaati peraturan sekolah adalah meliputi: dapat mengatur waktu belajar di rumah, rajin dan teratur belajar, perhatian yang baik saat belajar di kelas, dan ketertiban diri saat belajar di kelas.

"Untuk mengukur tingkat disiplin belajar mahasiswa diperlukan indikator-indikator mengenai disiplin belajar seperti yang diungkapkan Moenir (2010: 96) indikator-indikator yang dapat digunakan untuk mengukur tingkat disiplin belajar mahasiswa berdasarkan ketentuan disiplin waktu dan disiplin perbuatan, yaitu:

a. Disiplin Waktu, meliputi :

1. Tepat waktu dalam belajar, mencakup datang dan pulang sekolah tepat waktu, mulai dari selesai belajar di rumah dan di sekolah tepat waktu
a) Tidak
meninggalkan
kelas/membolos
saat
pelajaran
b) Menyelesaikan tugas sesuai waktu yang ditetapkan.

2. Disiplin Perbuatan, meliputi :

a) Patuh dan tidak menentang peraturan yang berlaku

b) Tidak malas belajar

c) Tidak menyuruh orang lain bekerja demi dirinya

d) Tidak suka berbohong

e) Tingkah laku menyenangkan, mencakup tidak mencontek, tidak membuat keributan, dan tidak mengganggu orang lain yang sedang belajar.

\section{Motivasi Belajar}

Motivasi belajar adalah dorongan internal dan eksternal pada Mahasiswa-Mahasiswa yang sedang belajar untuk mengadakan perubahan tingkah laku".Macam-macam motivasi ada dua yaitu motivasi intrinsik dan motivasi ekstrinsik.

Menurut Amir (dalam Fathurrohman, 2012:153) faktorfaktor yang mempengaruhi motivasi intrinsik adalah kebutuhan, pengetahuan untuk kemajuan sendiri, aspirasi atau cita-cita.Sedangkan faktor-faktor yang memepngaruhi motivasi ekstrinsik adalah ganjaran, hukuman, persaingan atau kompetisi.

$$
\text { Menurut Uno (2008:23) }
$$
indikator motivasi belajar adalah adanya hasrat dan keinginan berhasil, adanya dorongan dan kebutuhan dalam belajar, adanya harapan dan cita-cita masa depan, adanya penghargaan dalam belajar, adanya kegiatan yang menarik dalam belajar. 


\section{Kreativitas Belajar}

Kreativitas Belajar Mahasiswa Menurut Hurlock (2005:4), "Kreativitas adalah kemampuan untuk menghasilkan komposisi, produk atau gagasan apa saja yang pada dasarnya baru dan sebelumnya tidak dikenal pembuatnya."

Sedangkan menurut Rogers (dalam Zulkarnain, 2002: 45), kreativitas merupakan kecenderungankecenderungan manusia untuk mengaktualisasikan dirinya sesuai dengan kemampuan yang dimilikinya. Kreativitas yang timbul antara Mahasiswa satu dengan yang lain berbedabeda. Ada Mahasiswa yang berkreativitas tinggi dan ada Mahasiswa yang berkreativitas yang rendah, sehingga aktivitas yang dilakukan berbeda pula tergantung tinggi rendahnya kreativitas yang ada pada diri Mahasiswa. Semakin Mahasiswa memiliki kreativitas yang tinggi maka Mahasiswa tersebut akan semakin giat dalam belajarnya untuk mencapai prestasi yang maksimal.

Munandar

(2009:

menyatakan kreativitas merupakan kemampuan berpikir divergen atau pemikiran menjajaki bermacammacam alternatif jawaban terhadap suatu persoalan, yang sama benarnya. Kreativitas dapat didefinisikan secara inklusif, yaitu meliputi semua usaha produktif yang unik dari individu.dengan kata lain kreativitas dapat diartikan sebagai pola berfikir yang timbul secara spontan dan imajinatif, yang bercirikan hasil artistik, penemuan ilmiah, dan penciptaan mekanik. dalam proses kreativitas ada dua pandangan yaitu:

1. Pandangan Asosiasi

Menyatakan bahwa kreativitas menyangkut pembentukan asosiasi stimulus-respons.jadi pandangan ini menekankan pada asosiasi yang dipelajari sebelumnya yang dihidupkan kembali kemudian dirangkaikan.

2. Pandangan Kognitif

Menyatakan bahwa kreativitas melibatkan penggabungan gagasan dan informasi dalam cara baru yang berbeda. jadi pandangan ini menekankan bahwa analisis kognitif kreativitas tidak sematamata pada asosiasi yang luar biasa tetapi pada gagasan baru yang bermakna. contohnya ketrampilan berpikir lancar, ketrampilan berfikir luwes atau fleksibel, ketrampilan berpikir orisional, ketrampilan merinci atau mengelaborasi serta ketrampilan menilai.

\section{METODE PENELITIAN Jenis Penelitian}

Pendekatan yang digunakan dalam penelitian ini adalah pendekatan kuantitatif, karena metode kuantitatif adalah metode penelitian yang digunakan untuk meneliti pada populasi atau sampel tertentu, pengumpulan data menggunakan instrumen penelitian, analisis data bersifat kuantitatif atau analisis 
statistik dengan tujuan untuk menguji hipotesis yang telah ditetapkan.

\section{Tempat dan Waktu Penelitian}

Penelitian ini dilakukan di Universitas PGRI Yogyakarta pada bulan Maret sampai dengan Juni 2017.

\section{Variabel Penelitian}

Dalam penelitian ini terdapat tiga variabel, yaitu dua variabel bebas dan variabel terikat.

a. Variabel bebas merupakan variabel yang mempengaruhi atau menjadi sebab terjadinya perubahan atau menjadi sebab variabel terikat, variabel bebas disebut juga dengan variabel independen. Dalam penelitian ini, variabel bebas adalah disiplin belajar (X1) dan motivasi belajar (X2).

b. Variabel terikat merupakan variabel yang dipengaruhi oleh variabel bebas atau menjadi akibat dari adanya variabel bebas, variabel terikat disebut juga dengan variabel dependen. Dalam penelitian ini variabel terikatnya adalah kreativitas belajar (Y).

\section{Populasi dan Sampel}

Populasi merupakan wilayah yang terdiri dari objek atau subjek yang memiliki karakteristik tertentu yang ditetapkan oleh peneliti untuk dipelajari dan ditarik kesimpulan. Populasi juga bukan hanya jumlah objek atau subjek yang ada melainkan juga semua karakteristik dan sifat yang dimiliki oleh objek atau subjek tersebut (Sugiyono 2013: 80). Dalam penelitian ini populasinya adalah Mahasiswa program Studi Bimbingan dan Konseling angkatan 2015/2016 yang terdiri dari 4 kelas ( A 1, A2, A3, dan A 4) sejumlah 149 Mahasiswa.

Sampel adalah Sampel adalah sebagian dari jumlah dan karakteristik yang dimiliki oleh populasi tersebut. Karena populasi penelitian ini jumlah populasinya diatas 100 (seratus), maka penelitian ini akan menggunakan sampel. Seperti halnya yang dikemukakan oleh Suharsimi Arikunto, (2002) bahwa : Apabila subyeknya kurang dari 100, maka lebih baik diambil semua sehingga penelitiannya merupakan penelitian populasi. Jika jumlahnya subyeknya besar dapat diambil antara $10-15 \%$ atau $20-25 \%$ atau lebih, atau tergantung setidak-tidaknya dari :

a. Kemampuan peneliti dilihat dari waktu, tenaga dan dana.

b. Sempit luasnya wilayah pengamatan dari subyek, karena hal ini menyangkut banyak sedikitnya data.

c. Besar kecilnya risiko yang ditanggung oleh peneliti. Untuk penelitian yang resikonya besar, tentu saja jika sampel besar, hasilnya akan lebih baik.

Penelitian ini menggunakan QuotaProportionate Random Sampling yaitu pengambilan sampel dari populasi dilakukan secara acak dan populasi mempunyai anggota/unsur yang tidak homogen 
dan berstrata secara proporsional (Sugiyono, 2007). Penentuan jumlah anggota sampel dalam penelitian ini yaitu dengan mengambil $20 \%$ dari anggota populasi. Setelah menghitung jumlah anggota sampel dengan mengambil $20 \%$ dari anggota populasi maka, dapat diketahui sampel dalam penelitian ini berjumlah 129 orang.

\section{Teknik Pengumpulan data}

Pengumpulan data yang digunakan adalah angket.Angket yang digunakan dalam penelitian ini adalah angket tertutup, dimana responden tidak diberikan kesempatan untuk memberi jawaban dengan kata-kata sendiri.Responden hanya memberi tanda silang pada jawaban yang telah disediakan.Alternatif jawaban berupa multiple choice seperti a, b, c, dan d.

\section{Teknik Analisis Data}

Teknik analisis data dalam penelitian ini meliputi analisis statistik deskriptif dan statistik inferensial. Statistik deskriptif yaitu statistik yang digunakan untuk menganalisis data dengan cara mendeskripsikan atau menggambarkan data yang telah terkumpul sebagaimana adanya tanpa bermaksud membuat kesimpulan yang berlaku untuk umum atau generalisasi (Sugiyono, 2013: 147). Sedangkan statistik inferensial adalah teknik statistik yang digunakan untuk menganalisis data sampel dan hasilnya diberlakukan untuk populasi. Dalam penelitian ini, analisis statistik deskriptif digunakan untuk mendiskripsikan hasil data penelitian, sedangkan analisis statistik inferensial digunakan untuk menganalisis data seluruh subjek yang digunakan untuk penelitian.

Rumus Regresi :

$\mathrm{Y}=\mathrm{a}+\mathrm{b} 1 \mathrm{X} 1+\mathrm{b} 2 \mathrm{X} 2$

Keterangan :

$\mathrm{Y} \quad=$ Kreativitas belajar

a $\quad=$ Konstanta yang merupakan intersep $\mathrm{X}$ garis antara dan $\mathrm{Y}$

b1 = Koefisien perubah bebas antara X1 terhadap Y

b2 = Koefisien perubah bebas antara X2 terhadap Y

$\mathrm{X} 1=$ Disiplin belajar

$\mathrm{X} 2=$ Motivasi belajar

\section{HASIL PENELITIAN DAN PEMBAHASAN}

Hasil dari perhitungan dapat diketahui bahwa hasil uji $\mathrm{t}$ untuk variabel disiplin belajar (X1) diperoleh hasil t hitung sebesar 9,289 dengan probabilitas sebesar 0,000 . Nilai probabilitas lebih kecil dari 0,05 $(0,000<0,05)$ maka dengan demikian Ha diterima. Jadi dapat dikatakan bahwa ada pengaruh antara disiplin belajar terhadap kreativitas belajar Mahasiswa Bimbingan dan Konseling angkatan 2015/2016.

Hasil uji t untuk variabel (X2) diperoleh hasil t hitung sebesar 3,922 dengan probabilitas sebesar 0,000 . Nilai probabilitas lebih kecil dari 0,05 $(0,000<0,05)$ maka dengan demikian Ha diterima. Jadi dapat dikatakan bahwa ada pengaruh motivasi belajar terhadap kreativitas Mahasiswa 
Bimbingan dan Konseling angkatan 2015/2016.

Hasil analisis regresi berganda diperoleh koefisien untuk variabel bebas $\mathrm{X} 1=0,667$ dan $\mathrm{X} 2=0,392$ dengan konstanta sebesar 22,741, sehingga model persamaan regresi yang diperoleh adalah: $\mathrm{Y}=22,741+$ $0,667 X 1+0,392 X 2$.

Dimana:

$\mathrm{Y}=$ Variabel terikat kreativitas belajar

$\mathrm{X} 1=$ Variabel bebas (Disiplin belajar) $\mathrm{X} 2$ = Variabel bebas (motivasi belajar)

1. Variabel disiplin belajar dan motivasi belajar berpengaruh positif terhadap kreativitas belajar.

2. Nilai konstanta (Y) sebesar 22,741 yang artinya adalah jika disiplin belajar dan motivasi belajar sama dengan nol, maka kreativitas Mahasiswa akan menjadi sebesar 22,741

3. Koefisien regresi X1 (Disiplin belajar) dari perhitungan regresi berganda diperoleh nilai koefisien (b1) $=0,667$. Hal ini berarti setiap ada peningkatan disiplin belajar (X1), maka akan diikuti peningkatan kreativitas belajar Mahasiswa (Y) sebesar 0,667 apabila variabel motivasi belajar (X2) adalah konstan.

4. Koefisien regresi X2 (Kreativitas belajar) dari perhitungan regresi berganda didapat nilai koefien (b2) $=0,392$. Hal ini berarti setiap ada peningkatan motivasi belajar (X2), maka akan diikuti peningkatan kreativitas Mahasiswa (Y) sebesar
0,392 apabila variabel disiplin belajar (X1) adalah konstan.

Disiplin belajar merupakan cermin langsung dari kepatuhan seorang Mahasiswa dalam melaksanakan peraturan-peraturan yang berlaku di kampusnya. Kepatuhan Mahasiswa tersebut akan mendorong terciptanya kegiatan belajar mengajar yang efektif dan berguna untuk hasil belajar yang optimal. Dengan demikian menunjukkan bahwa disiplin belajar sangat dibutuhkan untuk mendukung terciptanya kreativitas dan hasil belajar yang optimal.Sebaliknya ada Mahasiswa yang hasil belajarnya kurang memuaskan meskipun tingkat kecerdasannya baik atau sangat baik, hal ini terjadi karena mahasiswa kurang tertib dan kurang teratur belajar.

Persamaan garis regresi yang terbentuk dalam penelitian ini adalah $\mathrm{Y}=22,741+0,667 \mathrm{X} 1+0,392 \mathrm{X} 2$ persamaan tersebut kemudian diuji kebermaknaannya baik dengan uji $\mathrm{F}$ maupun uji t, didapatkan bahwa persamaan regresi berganda tersebut signifikan, artinya dapat digunakan untuk mendeteksi hasil belajar akuntansi bila hanya dipengaruhi disiplin belajar dan kreativitas belajar. Dengan demikian hipotesis yang menyatakan bahwa "Ada pengaruh positif disiplin belajar dan motivasi belajar terhadap kreativitas belajar Mahasiswa Bimbingan dan Konseling" diterima. 
Berarti disiplin belajardan motivasi belajar berpengaruh positif terhadap kreativitas belajar Mahasiswa. Kemudian hasil perhitungan dari sumbangan relatif dan sumbangan efektif, kreativitas belajar mahasiswa memberikan sumbangan relatif sebesar $34,70 \%$ dan sumbangan efektif 7,36\%. Dengan demikian dapat dikatakan bahwa semakin tinggi disiplin belajar dan motivasi belajar Mahasiswa maka semakin tinggi kreativitas belajar Mahasiswa. Sebaliknya, semakin rendah disiplin belajar dan motivasi belajar Mahasiswa maka semakin rendah pula kreativitas belajar Mahasiswa.

\section{KESIMPULAN DAN SARAN}

Berdasarkan hasil penelitian dan pembahasan yang terdapat pada bab IV maka dapat diambil kesimpulan sebagai berikut.

1. Ada pengaruh positif disiplin belajar terhadap kreativitas belajar Mahasiswa BK diperoleh $\mathrm{F}$ hitung 73,529 dan nilai $\mathrm{R}$ square sebesar $53,90 \%$

2. Ada pengaruh positif motivasi belajar terhadap kreativitas belajar Mahasiswa BK diperoleh t hitung sebesar 9,289 dan $\mathrm{r}^{2} 40,70 \%$

3. Ada pengaruh positif disiplin belajar dan motivasi belajar terhadap kreativitas belajar Mahasiswa BK diperoleh t hitung sebesar 3,922 dan $\mathrm{r}^{2} 10,89 \%$
Berdasarkan hasil kesimpulan di atas maka dapat dikemukakan saran sebagai berikut:

1. Bagi orang tua hendaknya harus menanamkan kebiasaan belajar yang baik dan disiplin diri dengan selalu mengontrol dan memperhatikan.

2. Lembaga hendaknya memberikan fasilitas penunjang yang efektif sebagai media untuk memacu peningkatan kreativitas mahasiswa seperti dengan diadakannya internet, dan menambah koleksi buku-buku di perpustakaan.

Bagi peneliti lain untuk melakukan penelitian serupa guna mencari sumbangan dari faktor lain yang dapat mempengaruhi kreativitas belajar mahasiswa.

\section{DAFTAR PUSTAKA}

Ali, Muhammad. 1994. Prosedur Penelitian Pendidikan. Jakarta: Reneka Cipta.

Anni Cattarina Tri dkk. 2004. Psikologi Belajar. Semarang: UPT MKK UNNES.

Dalyono, M. 2005. Psikologi Pendidikan. Jakarta: Rineka Cipta.

Dimyati dan Mudjiono. 1994. Belajar dan Pembelajaran. Jakarta: Depdikbud.

Ghozali, Imam. 2006. Aplikasi Analisis Multivariate dengan 
Program SPSS. Semarang: Badan Penerbit UNDIP.

Mulyasa, E. 2002. Kurikulum Berbasis

Kompetensi. Bandung:

Rosdakarya.

Munandar, Utami. 1999. Kreativitas dan Keberbakatan. Jakarta: PT Gramedia Pustaka Utama.

Sardiman, AM. 2006. Interaksi dan Motivasi Belajar Mengajar. Jakarta. Raja Grafindo Jaya Persada .

Sudjana, Nana. 2002. Metode Statistika. Bandung : Tarsito.

Suharsimi Arikunto. 1990.

Manajemen Pengajaran secara Manusiawi. Jakarta: Rineka Cipta.

2002. Prosedur Penelitian Suatu Pendekatan Praktik. Jakarta: Rineka Cipta. 